\title{
Geographical distribution and host range of mono- xenous trypanosomatid Crithidia brevicula (Frolov et Malysheva, 1989) in the northern regions of Eurasia
}

\author{
Anna I. Ganyukova, Andrew V. Zolotarev and \\ Alexander O. Frolov \\ Zoological Institute, Russian Academy of Sciences, St. Petersburg, Russia
}

| Submitted March 20, 2020 | Accepted April 17, 2020|

\begin{abstract}
Summary
The article provides characteristics of seven new isolates of monoxenous trypanosomatid Crithidia brevicula, which were isolated from the hindgut of Brachyceran flies in the northern regions of Russia. Comparison of the SSU rRNA gene sequences and subsequent phylogenetic analysis based on this marker have demonstrated that new isolates form a reliable cluster with other isolates of $C$. brevicula from Hemipteran and Nematoceran insects.
\end{abstract}

Key words: Brachycera, Crithidia brevicula, Diptera, geographical distribution, host range, phylogeny, Trypanosomatidae

\section{Introduction}

Flagellates of the family Trypanosomatidae are widespread single-cellular organisms parasitizing invertebrates, plants and vertebrates. Based on the life cycle this group can be contingently divided into monoxenous ("one-host") and dixenous ("two-hosts") parasites. Dixenous parasites from the genera Trypanosoma and Leishmania are the most well-known pathogenic agents of numerous significant human diseases (e.g. sleeping sickness, Chagas disease, kala-azar, espundia, oriental sore, etc.), as well as those of wild and domestic animals (e.g. nagana, surra, or dourine) (Hoare, 1972). The majority of monoxenous trypanosomatids parasitize insect hosts, predominantly from Hemiptera and Diptera orders (Podlipaev, 1990).

Previously, studies of monoxenous species were carried out according to the "residual principle", i.e. dealing mainly with the species of significant practical importance such as Trypanosoma and Leishmania that are predominantly found in tropical regions. Therefore, in general, the diversity of monoxenous trypanosomatids remains understudied, especially outside the areas of pathogenic species distribution.

Recently, interest to monoxenous trypanosomatids has increased significantly. This results from the wide variety of their host groups (Podlipaev, 2001; Maslov et al., 2013; Týč et al., 2013) as well as their important phylogenetic value. Now there is no doubt that those were monoxenous insect parasites, which composed the ancestral forms of the whole family (Frolov et al., 2015a). One of the most significant findings was the recent discovery and description of the new genus Paratrypanosoma. Monoxenous flagellates Paratrypanosoma confusum, found in the intestines of mosquito culicids, are positioned at the base of trypanosomatid phylogenetic tree between 
free-living kinetoplastids and the parasitic family Trypanosomatidae (Flegontov et al., 2013).

The diversity of monoxenous trypanosomatids in the Northwest Russia has been extensively studied since the 1980s. Many years of studies resulted in descriptions of new species (Frolov and Malysheva, 1989a, 1993; Frolov et al., 2017), new knowledge on the area expansion of existing species (Ganyukova et al., 2017), as well as descriptions of trypanosomatids' life cycles (Frolov et al., 2016). However, most of those studies dwell upon trypanosomatids parasitizing in hemipteran insects, and only a small number of works cover parasitic fauna of Diptera (Podlipaev and Frolov, 1999; Ganyukova et al., 2017). This fact is largely paradoxical, because it is the dipteran insects that have recently been considered the most likely ancestral hosts of monoxenous trypanosomatids, and the exploitation of other insect orders by trypanosomatids resulted from original trypanosomatid life cycles being multiply transformed (Frolov et al., 2015a, 2015b).

The present work is carried out within the framework of studying trypanosomatids parasitizing dipteran insects in Northern Eurasia. The article describes cases of Crithidia brevicula (Frolov et Malysheva, 1989) infection in North Eurasian flies.

\section{Material and methods}

Insects were collected during field works in 2018-2019 in the following Russian regions: Vorkuta, the Republic of Komi $\left(67^{\circ} 35\right.$ N, $63^{\circ} 47$ E), Sob' village, Yamalo-Nenets Autonomous Area $\left(67^{\circ} 06 \mathrm{~N}, 65^{\circ} 61 \mathrm{E}\right)$, and in the vicinity of the marine biological station "Kartesh" (Zoological Institute, Russian Academy of Sciences), the Republic of Karelia $\left(66^{\circ} 17^{\prime} \mathrm{N}, 33^{\circ} 38^{\prime} \mathrm{E}\right)$.

Insects were euthanized in chloroform and dissected in a drop of physiological saline. Isolated intestine fragments with their contents were studied for infection. The intestinal fragments infected by the flagellates were placed in Brain Heart Infusion (BHI) nutrient tubes by Difco. Hemin $(25 \mu \mathrm{g} / \mathrm{ml})$, folic acid $(10 \mu \mathrm{g} / \mathrm{ml})$, and antibiotics solutions of benzylpenicillin at the rate of 500 units $/ \mathrm{ml}$ and streptomycin $500 \mu \mathrm{g} / \mathrm{ml}$ were added to the medium. Subsequently, the flagellate culture was purified from concomitant organisms in M-shaped tubes according to the methods previously described (Podlipaev and Frolov, 1987). Tissue fragments of infected insects were fixed in $96 \%$ ethanol.
Flagellates were studied on both intravital preparations and dried smears. Dried smears prepared from insect intestinal fragments or a drop of culture fluid were fixed for 10 minutes with 96\% ethanol. After drying, the slides were stained according to Romanowsky-Giemsa ( $\mathrm{pH}$ 6.8) for 30 minutes and washed with water. The studies were performed with a Leica DM 2500 microscope. Microphotographs were obtained with 14 MPs USB camera UCMOS14000KPA (TOUPCAM). Flagellate cell sizes were measured with UTHSCSA ImageTool v. 2.0. Statistical data (the mean and standard error of the mean) were processed with LibreOffice Calc.

Genomic DNA from flagellate cultures and host tissues fixed in 96\% ethanol was extracted using PureLink Genomic DNA Kit (Invitrogen) kit for DNA extraction. The $18 \mathrm{~S}$ gene fragment was amplified using specific primers UMx (5'-atc tggttgatcctgccagtagtca-3') and LMx (5'-ctacagctac cttgttacgacttttgc-3') (Kostygov et al., 2014). Amplification protocol and reaction mixture composition were described earlier (Kostygov and Frolov, 2007). The fragment of the insect's COI gene was amplified using LCOI and HCOI primers according to the previously described protocols (Cywinska et al., 2010). The resulting PCR fragments were extracted from the reaction mixture, purified with Cleanup Standard Kit (Eurogen) and sequenced with HiSeq 2500 (Illumina) automated sequencer using the Thermo Sequenase Cy5 Dye Terminator Kit. To identify and compare the obtained sequences of flies (COI) as well as trypanosomatids (18S rRNA), they were blasted against the GenBank database using the BLASTn program and compared with the BOLD database (for insects only).

The alignment of 58 SSU rRNA gene sequences of trypanosomatids representing the known phylogroups of these flagellates was prepared as described earlier using the MEGA (Molecular Evolutionary Genetic Analysis Version 5.05, www.megasoftware. net) software package (Schwarz et al., 2015). The final file included 58 sequences of the trypanosomatid 18S rRNA gene using the Paratrypanosoma confusum as an external group. The final file contained 2147 positions including indels. Phylogenetic analysis of the sequences was performed according the Bayes method with MrBayes 3.2.7 software using GTR $+\mathrm{G}$ + I model and gamma corrections with the following parameters: 4 Markov chains, 3 million generations, tree selection after each 100 generations, removal of the first 10000 trees while building consensus. 


\section{Results}

Among trypanosomatid cultures obtained from flies' rectums during field studies in 2018-2019, 7 isolates were identified as Crithidia brevicula based on the SSU rRNA gene fragments. The samples Kat4, S10, S14, S15, S24, Yu2 and Kar3 were isolated in axenic laboratory cultures. Axenic cultures were kept at $20^{\circ} \mathrm{C}$ and passaged monthly. Their cells were cryopreserved in the growth media supplemented with $10 \%$ DMSO (SigmaAldrich) and stored at $-86^{\circ} \mathrm{C}$. Cultures are deposited in the cell culture collection of the Zoological Institute of the Russian Academy of Sciences (Malysheva et al., 2016).

For genetic identification of insect hosts, $\sim 530$ bp fragments of the mitochondrial COI gene were successfully amplified. The sequence of the S14 fly was short (316 bp) and of low quality after the repeated attempts, which may be associated with poor preservation of the material during fixation. Blasting against the GenBank and/or BOLD databases reveal many highly similar sequences belonging to five families of the suborder Brachycera (Table 1).

In the phylogenetic tree constructed upon SSU rRNA genes analysis isolates Kat4, S10, S14, S15, S24, Yu2 and Kar3 are positioned within the group of infrafamily Crithidiatae (Kostygov and Yurchenko, 2017). They are identical to $C$. brevicula sequences submitted to GenBank system (Fig. 1). SSU rRNA gene sequences of new $C$. brevicula isolates are deposited to the GenBank system under the accession numbers MT232051-MT232057.

In laboratory cultures $C$. brevicula cells are represented by three main morphotypes: promastigotes, endomastigotes, and brochomastigotes (Fig. 2). The last one is specific to the given species. Morphometric characteristics of particular morphotypes are provided in details in Table 2.

Promastigotes are usually elongated. The nuceus is located in the middle of the cell; the kinetoplast is displaced to the front end (Fig. 2, A). Cells of this type are relatively large. Their length in different isolates varies on average from 6.76 to $10.24 \mu \mathrm{m}$, width - from 2.06 to $2.46 \mu \mathrm{m}$. The flagellum is well-defined; its length starting from the kinetoplast can reach $14.50 \mu \mathrm{m}$ (Table 2). The proportion of promastigotes in all cultures was $81-92 \%$ (Table 3 ).

The second morphotype, endomastigotes (Fig. $2, \mathrm{~B}$ ), is characterized by a shortened flagellum that does not exceed the flagellar pocket. Nucleus
Table 1. List of hosts and regions for Crithidia brevicula isolates from flies.

\begin{tabular}{|c|l|l|}
\hline Isolate & \multicolumn{1}{|c|}{ Host } & \multicolumn{1}{c|}{ Region } \\
\hline Kat4 & $\begin{array}{l}\text { Calliphora uralensis } \\
\text { (Brachycera: Calliphorida) }\end{array}$ & $\begin{array}{l}\text { Vorkuta, Komi Rep. } \\
\left(67^{\circ} 35 \mathrm{~N}, 63^{\circ} 47 \mathrm{E}\right)\end{array}$ \\
\hline $\mathrm{S} 10$ & $\begin{array}{l}\text { Mesembrina meridiana } \\
\text { (Brachycera: Muscidae) }\end{array}$ & $\begin{array}{l}\text { Sob', YNAA } \\
\left(67^{\circ} 06 \mathrm{~N}, 65^{\circ} 61 \mathrm{E}\right)\end{array}$ \\
\hline $\mathrm{S} 14$ & $\begin{array}{l}\text { Heleomyza sp. (Brachycera: } \\
\text { Heleomyzidae) }\end{array}$ & $\begin{array}{l}\text { Sob', YNAA } \\
\left(67^{\circ} 06 \mathrm{~N}, 65^{\circ} 61 \mathrm{E}\right)\end{array}$ \\
\hline $\mathrm{S} 15$ & $\begin{array}{l}\text { Nemopoda nitidula } \\
\text { (Brachycera: Sepsidae) }\end{array}$ & $\begin{array}{l}\text { Sob', YNAA } \\
\left(67^{\circ} 06 \mathrm{~N}, 65^{\circ} 61 \mathrm{E}\right)\end{array}$ \\
\hline S24 & $\begin{array}{l}\text { Stomoxys calcitrans } \\
\text { (Brachycera: Muscidae) }\end{array}$ & $\begin{array}{l}\text { Sob', YNAA } \\
\left(67^{\circ} 06 \mathrm{~N}, 65^{\circ} 61 \mathrm{E}\right)\end{array}$ \\
\hline Yu2 & $\begin{array}{l}\text { Anthomyia pluvialis } \\
\text { Brachycera: Antomyidae }\end{array}$ & $\begin{array}{l}\text { "Kartesh", Karelia Rep. } \\
\left(66^{\circ} 17 \mathrm{~N}, 33^{\circ} 38 \mathrm{E}\right)\end{array}$ \\
\hline Kar3 & $\begin{array}{l}\text { Cynomya mortuorum } \\
\text { (Brachycera: Calliphorida) }\end{array}$ & $\begin{array}{l}\text { "Kartesh", Karelia Rep. } \\
\left(66^{\circ} 17 \mathrm{~N}, 33^{\circ} 38 \mathrm{E}\right)\end{array}$ \\
\hline
\end{tabular}

located in the middle of the cell; the kinetoplast can be displaced to the nucleus. Cells of this type have shortened size; average length of different isolates vary from 4.78 to $5.64 \mu \mathrm{m}$, width - from 2.23 to $2.51 \mu \mathrm{m}$ (Table 2). The endomastigotes' proportion in cultures ranged from 4 to $11 \%$ (Table 3 ).

Brochomastigote is a specific morphotype, characteristic of $C$. brevicula (Fig. 2, C). Its peculiarity is a loop-shaped laying of the flagellum, due to which it bends around the nucleus. Their length vary on average from 5.45 to $8.58 \mu \mathrm{m}$, width - from 2.16 to $2.98 \mu \mathrm{m}$ depending on the isolate (Table 2). As a rule, flagellum does not extend beyond the flagellar pocket. The brochomastigotes' proportion in all isolate cultures ranged from 4 to $10 \%$ (Table 3).

\section{Discussion}

C. brevicula is a widespread flagellate found in Northwestern Russia and Central Europe. It was first described in 1989 from intestine of the bug Nabis brevis Scholtz, 1847 (Heteroptera: Nabidae) (Frolov and Malysheva, 1989a). However, further investigations showed wide hostal specificity of this species: today the range of its confirmed hosts in Northwestern Russia includes bugs of 3 families: Miriidae, Gerridae and Nabidae (Kostygov et al., 2014). C. brevicula infections were observed in different bug species in the Leningrad region, the Republic of Karelia, as well as in the Pskov region (Kostygov et al., 2014) (Fig. 3).

Until recently, C. brevicula was considered a parasite associated only with Hemipteran insects. Meanwhile, recently this species was noted in two 


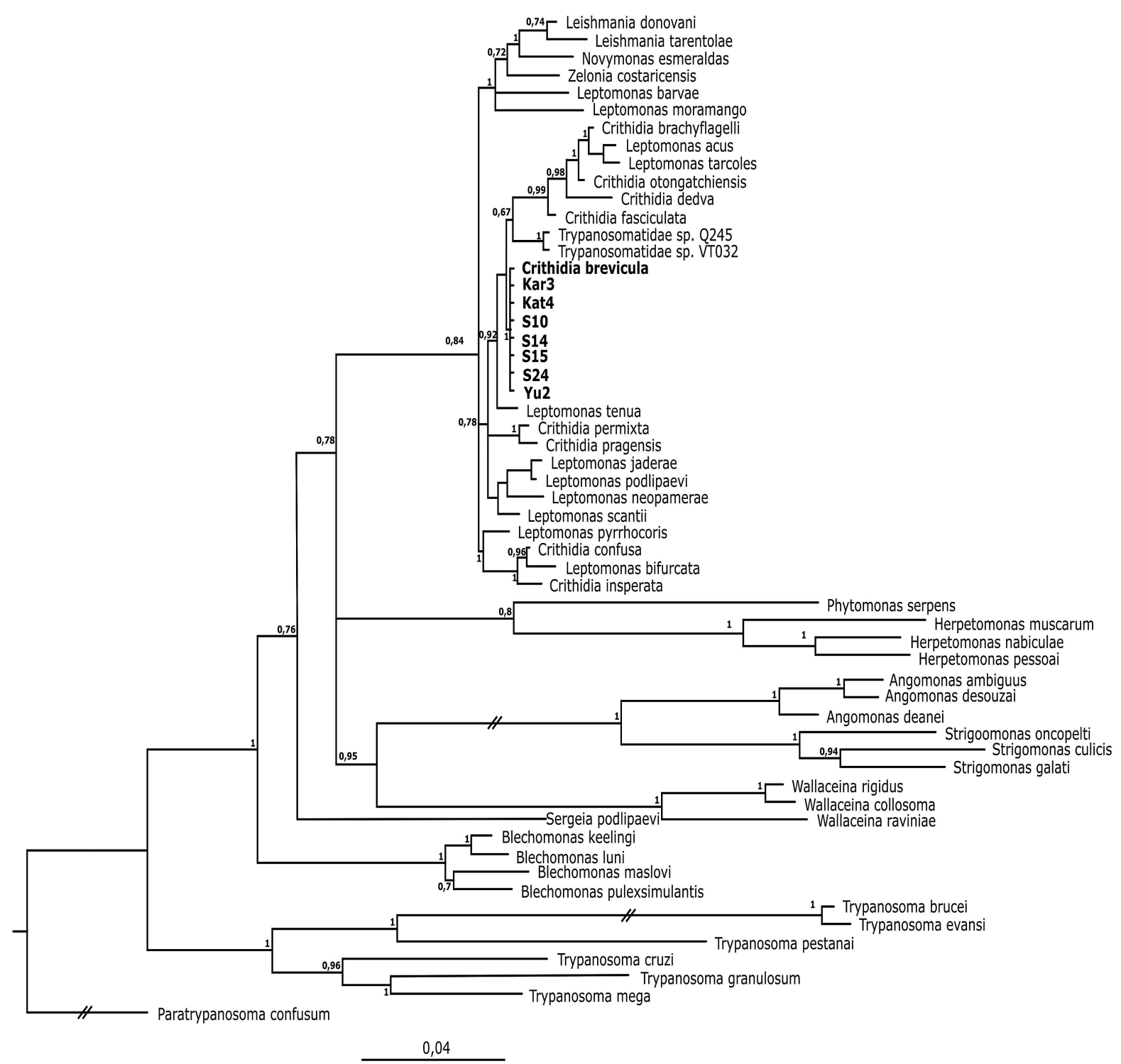

Fig. 1. Bayesian phylogenetic tree reconstructed using $18 \mathrm{~S}$ ribosomal RNA gene sequences. Numbers at nodes indicate posterior probabilities. Double-crossed branches are at $1 / 3$ of their original lengths. The tree is rooted with the sequence of Paratrypanosoma confusum. The scale bar denotes the number of substitutions per site. The species and isolates under study are highlighted in bold. Accession numbers of the sequences retrieved from GenBank are available upon request.

species of mosquitoes - Culex modestus and $C$. pipens in the Czech Republic and Austria. Nowadays these regions correspond to the southernmost boundary of the C. brevicula distribution (Schoener et al., 2018) (Fig. 3).

It is noteworthy that existing large-scale studies of the monoxenous trypanosomatids diversity have never found $C$. brevicula infection in tropical latitudes (Týč et al., 2013; Yurchenko et al., 2014). In addition, search for similar $18 \mathrm{~S}$ rRNA gene sequences in GenBank system has shown that this species was not discovered during barcoding studies outside European regions. In 2018 in the USA, a new Crithidia species was found in bumblebees intestines of Bombus impatiens and B. ternarius (Trypanosomatidae sp. voucher Q245-2 and Trypanosomatidae sp. voucher VT032, respectively). In the phylogenetic trees, this new species is positioned next to C. brevicula (Fig. 1) (Tripodi et al., 2018). Unfortunately, the new species was not isolated in 
74 • Anna I. Ganyukova, Andrew V. Zolotarev and Alexander O. Frolov

Table 2. Morphometry of Crithidia brevicula in the laboratory cultures.

\begin{tabular}{|c|c|c|c|c|c|c|c|}
\hline Morphotype & Isolate & $\begin{array}{l}\text { Cell length } \\
(\mu \mathrm{m})\end{array}$ & $\begin{array}{l}\text { Cell width } \\
(\mu \mathrm{m})\end{array}$ & $\begin{array}{c}\text { Nucleus } \\
\text { length }(\mu \mathrm{m})\end{array}$ & $\begin{array}{l}\text { Anterior end } \\
\text { to kinetoplast } \\
\text { distance }(\mu \mathrm{m})\end{array}$ & $\begin{array}{c}\text { Anterior end to } \\
\text { nucleus distance } \\
(\mu \mathrm{m})\end{array}$ & $\begin{array}{c}\text { Free flagellum } \\
\text { length } \\
(\mu \mathrm{m})\end{array}$ \\
\hline \multirow{7}{*}{ Promastigotes } & Kat 4 & $\begin{array}{l}6,76( \pm 1,11) \\
(5,17-8,57)\end{array}$ & $\begin{array}{l}2,17( \pm 0,22) \\
(1,95-2,72)\end{array}$ & $\begin{array}{l}1,81( \pm 0,18) \\
(1,53-2,11)\end{array}$ & $\begin{array}{l}2,22( \pm 0,37) \\
(1,63-2,78)\end{array}$ & $\begin{array}{l}2,87( \pm 0,69) \\
(2,04-4,49)\end{array}$ & $\begin{array}{c}9,22( \pm 1,49) \\
(7,02-11,57)\end{array}$ \\
\hline & $\mathrm{S} 10$ & $\begin{array}{l}7,23( \pm 1,40) \\
(4,75-9,30)\end{array}$ & $\begin{array}{l}2,13( \pm 0,28) \\
(1,58-2,63)\end{array}$ & $\begin{array}{l}1,95( \pm 0,18) \\
(1,58-2,19)\end{array}$ & $\begin{array}{l}2,03( \pm 0,49) \\
(1,43-2,75)\end{array}$ & $\begin{array}{l}2,68( \pm 0,71) \\
(1,58-4,07)\end{array}$ & $\begin{array}{l}10,30( \pm 2,30) \\
(5,88-13,03)\end{array}$ \\
\hline & $\mathrm{S} 14$ & $\begin{array}{l}8,03( \pm 1,13) \\
(3,73-6,08)\end{array}$ & $\begin{array}{l}2,23( \pm 0,22) \\
(1,67-2,93)\end{array}$ & $\begin{array}{l}1,90( \pm 0,25) \\
(1,18-1,89)\end{array}$ & $\begin{array}{l}1,72( \pm 0,36) \\
(1,29-2,58)\end{array}$ & $\begin{array}{l}2,71( \pm 0,36) \\
(1,77-3,07)\end{array}$ & $\begin{array}{l}8,27( \pm 1,40) \\
(1,27-2,48)\end{array}$ \\
\hline & $\mathrm{S} 15$ & $\begin{array}{c}8,61( \pm 1,15) \\
(6,03-10,11)\end{array}$ & $\begin{array}{l}2,34( \pm 0,54) \\
(1,73-3,26)\end{array}$ & $\begin{array}{l}2,02( \pm 0,39) \\
(1,25-2,55)\end{array}$ & $\begin{array}{l}1,98( \pm 0,34) \\
(1,57-2,76)\end{array}$ & $\begin{array}{l}3,21( \pm 0,62) \\
(2,52-4,34)\end{array}$ & $\begin{array}{c}9,59( \pm 1,44) \\
(7,18-12,05)\end{array}$ \\
\hline & $\mathrm{S} 24$ & $\begin{array}{c}9,58( \pm 0,93) \\
(8,59-11,56)\end{array}$ & $\begin{array}{l}2,46( \pm 0,29) \\
(2,08-3,04)\end{array}$ & $\begin{array}{l}1,98( \pm 0,23) \\
(1,48-2,27)\end{array}$ & $\begin{array}{l}1,78( \pm 0,54) \\
(0,95-2,69)\end{array}$ & $\begin{array}{l}2,63( \pm 0,53) \\
(1,97-3,66)\end{array}$ & $\begin{array}{l}13,13( \pm 2,49) \\
(8,97-16,70)\end{array}$ \\
\hline & Kar3 & $\begin{array}{l}6,87( \pm 0,70) \\
(6,13-8,20)\end{array}$ & $\begin{array}{l}2,06( \pm 0,30) \\
(1,64-2,67)\end{array}$ & $\begin{array}{l}1,79( \pm 0,22) \\
(1,35-2,22)\end{array}$ & $\begin{array}{l}2,21( \pm 0,38) \\
(1,35-2,52)\end{array}$ & $\begin{array}{l}2,80( \pm 0,34) \\
(2,40-3,61)\end{array}$ & $\begin{array}{l}7,05( \pm 0,86) \\
(6,48-8,84)\end{array}$ \\
\hline & Yu2 & $\begin{array}{l}10,24( \pm 1,27) \\
(8,91-12,93)\end{array}$ & $\begin{array}{l}2,13( \pm 0,22) \\
(1,77-2,56)\end{array}$ & $\begin{array}{l}2,19( \pm 0,26) \\
(1,90-2,74)\end{array}$ & $\begin{array}{l}2,41( \pm 0,52) \\
(1,80-3,19)\end{array}$ & $\begin{array}{l}3,62( \pm 0,62) \\
(2,70-4,84)\end{array}$ & $\begin{array}{c}14,50( \pm 2,46) \\
(11,87-19,77)\end{array}$ \\
\hline \multirow{7}{*}{ Endomastigotes } & Kat 4 & $\begin{array}{l}4,78( \pm 0,81) \\
(3,69-5,83)\end{array}$ & $\begin{array}{l}2,26( \pm 0,40) \\
(1,82-2,85)\end{array}$ & $\begin{array}{l}1,54( \pm 0,26) \\
(1,04-2,00)\end{array}$ & $\begin{array}{l}2,09( \pm 0,58) \\
(1,36-3,05)\end{array}$ & $\begin{array}{l}2,41( \pm 0,60) \\
(1,44-3,36)\end{array}$ & - \\
\hline & $\mathrm{S} 10$ & $\begin{array}{l}5,64( \pm 0,55) \\
(4,96-6,82)\end{array}$ & $\begin{array}{l}2,49( \pm 0,40) \\
(2,00-3,23)\end{array}$ & $\begin{array}{l}1,80( \pm 0,19) \\
(1,49-2,23)\end{array}$ & $\begin{array}{l}2,14( \pm 0,80) \\
(1,37-3,48)\end{array}$ & $\begin{array}{l}2,64( \pm 0,45) \\
(2,05-3,51)\end{array}$ & - \\
\hline & $\mathrm{S} 14$ & $\begin{array}{l}4,80( \pm 0,67) \\
(4,27-6,54)\end{array}$ & $\begin{array}{l}2,23( \pm 0,36) \\
(2,13-3,50)\end{array}$ & $\begin{array}{l}1,47( \pm 0,21) \\
(1,26-2,10)\end{array}$ & $\begin{array}{l}1,78( \pm 0,48) \\
(1,19-3,01)\end{array}$ & $\begin{array}{l}2,50( \pm 0,46) \\
(1,75-3,47)\end{array}$ & - \\
\hline & $\mathrm{S} 15$ & $\begin{array}{l}5,02( \pm 0,66) \\
(4,15-6,26)\end{array}$ & $\begin{array}{l}2,41( \pm 0,29) \\
(1,91-2,83)\end{array}$ & $\begin{array}{l}1,64( \pm 0,20) \\
(1,37-1,93)\end{array}$ & $\begin{array}{l}1,92( \pm 0,32) \\
(1,22-2,34)\end{array}$ & $\begin{array}{l}2,36( \pm 0,48) \\
(1,61-3,24)\end{array}$ & - \\
\hline & $\mathrm{S} 24$ & $\begin{array}{l}4,93( \pm 0,21) \\
(4,59-5,20)\end{array}$ & $\begin{array}{l}2,51( \pm 0,19) \\
(2,17-2,73)\end{array}$ & $\begin{array}{l}1,55( \pm 0,22) \\
(1,35-2,12)\end{array}$ & $\begin{array}{l}1,44( \pm 0,34) \\
(0,99-2,03)\end{array}$ & $\begin{array}{l}2,29( \pm 0,30) \\
(1,54-2,61)\end{array}$ & - \\
\hline & Kar3 & $\begin{array}{l}5,39( \pm 0,57) \\
(4,55-6,29)\end{array}$ & $\begin{array}{l}2,26( \pm 0,33) \\
(1,50-2,73)\end{array}$ & $\begin{array}{l}1,65( \pm 0,24) \\
(1,30-2,00)\end{array}$ & $\begin{array}{l}2,39( \pm 0,64) \\
(1,27-3,15)\end{array}$ & $\begin{array}{l}2,56( \pm 0,39) \\
(2,03-3,07)\end{array}$ & - \\
\hline & Yu2 & $\begin{array}{l}5,33( \pm 0,72) \\
(4,03-6,46)\end{array}$ & $\begin{array}{l}2,40( \pm 0,27) \\
(1,98-2,93)\end{array}$ & $\begin{array}{l}1,62( \pm 0,20) \\
(1,17-1,91)\end{array}$ & $\begin{array}{l}2,00( \pm 0,39) \\
(1,32-2,64)\end{array}$ & $\begin{array}{l}2,60( \pm 0,58) \\
(1,60-3,45)\end{array}$ & - \\
\hline \multirow{7}{*}{ Brochomastigotes } & Kat 4 & $\begin{array}{l}5,45( \pm 0,86) \\
(4,37-6,92)\end{array}$ & $\begin{array}{l}2,16( \pm 0,19) \\
(1,87-2,41)\end{array}$ & $\begin{array}{l}1,65( \pm 0,31) \\
(1,15-2,07)\end{array}$ & $\begin{array}{l}1,78( \pm 0,75) \\
(0,93-3,12)\end{array}$ & $\begin{array}{l}2,43( \pm 0,49) \\
(1,56-3,11)\end{array}$ & - \\
\hline & $\mathrm{S} 10$ & $\begin{array}{l}6,43( \pm 0,64) \\
(5,76-7,67)\end{array}$ & $\begin{array}{l}2,98( \pm 0,21) \\
(2,72-3,52)\end{array}$ & $\begin{array}{l}1,86( \pm 0,16) \\
(1,64-2,07)\end{array}$ & $\begin{array}{l}2,30( \pm 0,48) \\
(1,52-2,98)\end{array}$ & $\begin{array}{l}2,88( \pm 0,50) \\
(2,27-3,74)\end{array}$ & - \\
\hline & $\mathrm{S} 14$ & $\begin{array}{l}5,89( \pm 0,74) \\
(4,85-7,00)\end{array}$ & $\begin{array}{l}2,60( \pm 0,29) \\
(2,09-2,96)\end{array}$ & $\begin{array}{l}1,77( \pm 0,23) \\
(1,47-2,19)\end{array}$ & $\begin{array}{l}1,79( \pm 0,29) \\
(1,18-2,31)\end{array}$ & $\begin{array}{l}2,83( \pm 0,35) \\
(2,30-3,34)\end{array}$ & - \\
\hline & $\mathrm{S} 15$ & $\begin{array}{l}5,87( \pm 0,43) \\
(4,96-6,28)\end{array}$ & $\begin{array}{l}2,60( \pm 0,37) \\
(1,92-3,09)\end{array}$ & $\begin{array}{l}1,76( \pm 0,18) \\
(1,50-2,00)\end{array}$ & $\begin{array}{l}2,13( \pm 0,53) \\
(1,34-2,73)\end{array}$ & $\begin{array}{l}2,66( \pm 0,26) \\
(2,31-3,20)\end{array}$ & - \\
\hline & $\mathrm{S} 24$ & $\begin{array}{l}5,61( \pm 0,59) \\
(4,81-6,48)\end{array}$ & $\begin{array}{l}2,45( \pm 0,27) \\
(2,00-2,95)\end{array}$ & $\begin{array}{l}1,58( \pm 0,21) \\
(1,25-2,00)\end{array}$ & $\begin{array}{l}1,93( \pm 0,36) \\
(1,23-2,45)\end{array}$ & $\begin{array}{l}2,52( \pm 0,37) \\
(2,00-3,01)\end{array}$ & - \\
\hline & Kar3 & $\begin{array}{l}6,18( \pm 0,81) \\
(5,00-7,78)\end{array}$ & $\begin{array}{l}2,20( \pm 0,30) \\
(1,60-2,68)\end{array}$ & $\begin{array}{l}1,84( \pm 0,33) \\
(1,40-2,53)\end{array}$ & $\begin{array}{l}2,30( \pm 0,24) \\
(2,04-2,79)\end{array}$ & $\begin{array}{l}2,83( \pm 0,35) \\
(2,22-3,49)\end{array}$ & - \\
\hline & Yu2 & $\begin{array}{l}8,58( \pm 0,42) \\
(7,59-9,17)\end{array}$ & $\begin{array}{l}2,35( \pm 0,17) \\
(2,07-2,66)\end{array}$ & $\begin{array}{l}2,36( \pm 0,18) \\
(2,05-2,60)\end{array}$ & $\begin{array}{l}2,58( \pm 0,45) \\
(1,96-3,15)\end{array}$ & $\begin{array}{l}3,54( \pm 0,39) \\
(3,10-4,21)\end{array}$ & - \\
\hline
\end{tabular}



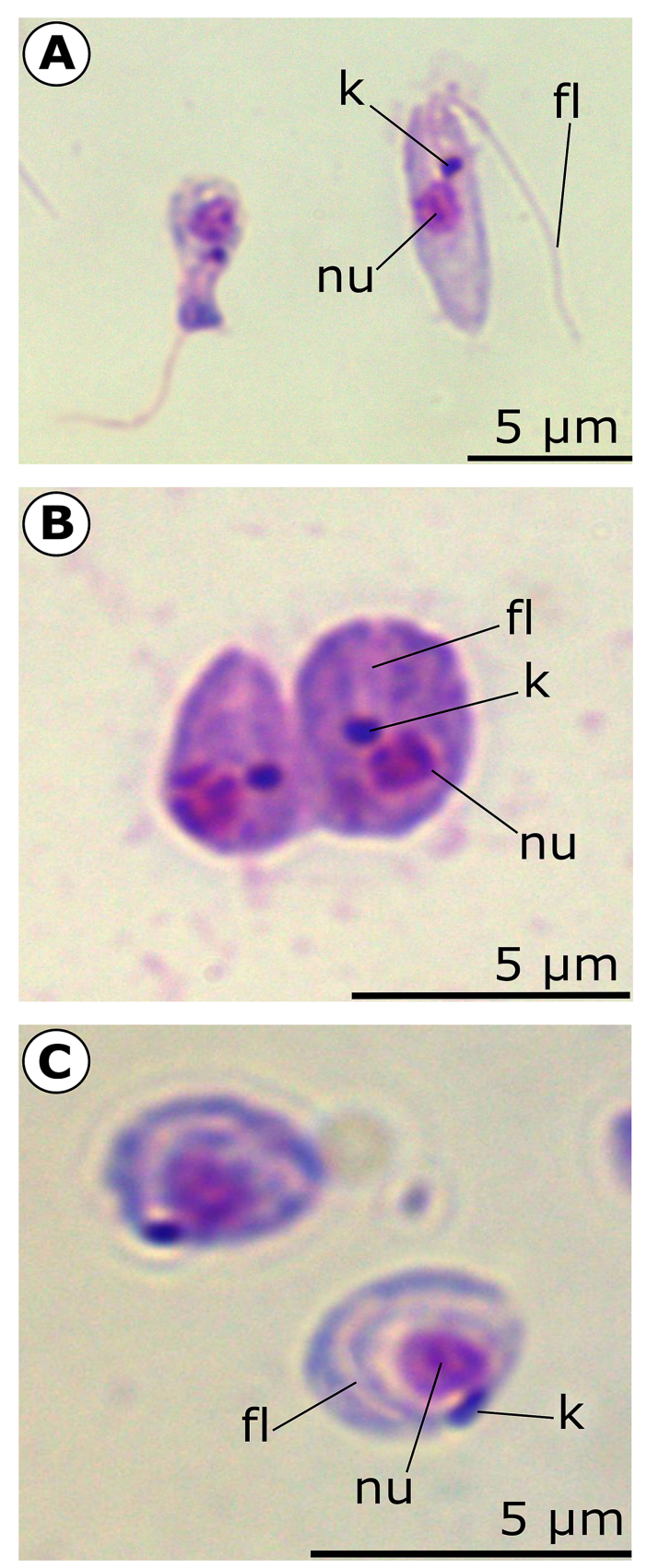

Fig. 2. Cells of Crithidia brevicula in cultures on Giemsa-stained smears. A - Promastigote cells; B - endomastigote cells; C - brochomastigote cells. Abbreviations: fl - flagellum; k - kinetoplast; $\mathrm{nu}-$ nucleus.

the culture and detailed studies of its biology are currently impossible. Moreover, the sequences submitted to the GenBank system are short and make up only 671 b.p. Therefore, it is not yet possible to establish reliable phylogenetic proximity of the new trypanosomatid parasite of Bombus spp. and C. brevicula.
Table 3. The percentage of Crithidia brevicula cells morphotypes in the laboratory cultures.

\begin{tabular}{|c|c|c|c|c|}
\hline Stain & $\begin{array}{c}\text { Promasti- } \\
\text { gotes \% }\end{array}$ & $\begin{array}{c}\text { Endomasti- } \\
\text { gotes \% }\end{array}$ & $\begin{array}{c}\text { Brochomasti- } \\
\text { gotes \% }\end{array}$ & $\begin{array}{c}\text { Total cell } \\
\text { counted \% }\end{array}$ \\
\hline Kat4 & 81 & 9 & 10 & 100 \\
\hline S10 & 86 & 7 & 7 & 100 \\
\hline S14 & 86 & 8 & 6 & 100 \\
\hline S15 & 86 & 7 & 7 & 100 \\
\hline S24 & 81 & 11 & 8 & 100 \\
\hline Kar3 & 88 & 5 & 7 & 100 \\
\hline Yu2 & 92 & 4 & 4 & 100 \\
\hline
\end{tabular}

Our studies enable to significantly expand current conceptions of geographic distribution and host range of C. brevicula. Isolates S10, S14, S15, S24 and Kat 4 are the only cases of trypanosomatid discovery beyond the Arctic Circle and mark the northern boundary of the species area. S10, S14, S15, S24 isolates' findings beyond the Ural Mountains indicate C. brevicula expansion to the Asian part of the continent (Fig. 3).

The discovered parasites are confined to the rectum of flies belonging to five families of the suborder Brachycera: Calliphorida (Calliphora uralensis, Cynomya mortuorum), Muscidae (Mesembrina meridiana, Stomoxys calcitrans), Heleomyzidae (Helomyza sp.), Sepsidae (Nemopoda nitidula), Antomyidae (Anthomyia pluvialis). Despite the diversity of families, biology of these flies is similar. Larvae develop in decaying substrates: dung and feces, corpses, decaying fungi and plants. Larvae of $C$. mortuorum and M. meridiana are able to switch from necro- and saprophagy to predation in the lack of food (Sedykh, 1974; Skidmore, 1985). The imago nutritional behavior is associated with alternation of nectaro-, copro- and saprophagia during their life cycles (Suchova, 1950; Sedykh, 1974; Skidmore, 1985; Ozerov, 2003; Krivosheina, 2008). An exception is the obligate hematophage $S$. calcitrans, previously not observed in the Far North regions. $S$. calcitrans forms part of gnat insect complex and is a mechanical carrier of staphylococcal infections, as well as pathogens of anthrax, sepsis, tularemia and other diseases (Ostroushko et al., 2007).

The life cycle of $C$. brevicula has been well studied in the intestines of bugs' family Nabidae (Frolov and Malysheva, 1989b; Frolov and Skarlato, 1995; Malysheva and Frolov, 1995). The cycle takes place in the insect rectum and includes two phases. 


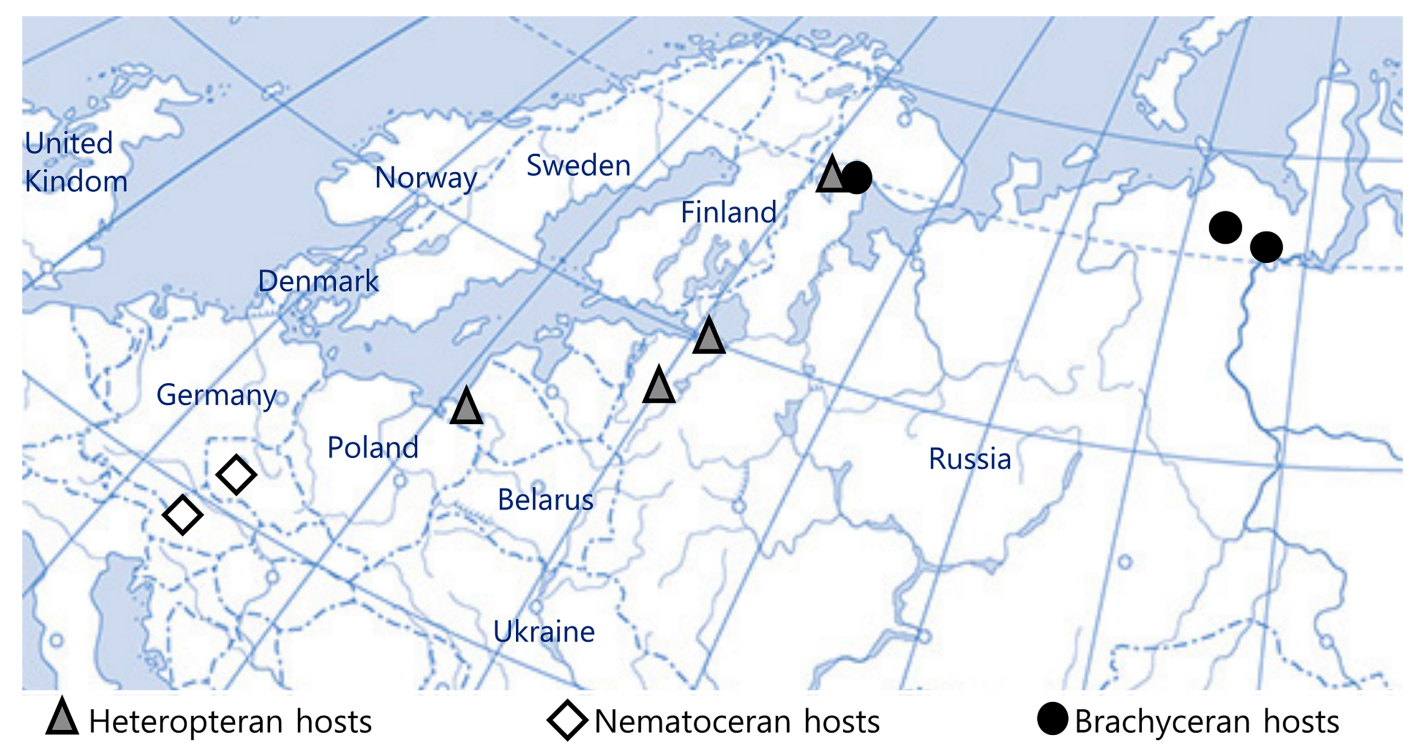

Fig. 3. Geographical distribution of the known Crithidia brevicula isolates.

The first phase is connected with endogenous agglomeration, when the cells are mainly represented by floating promastigotes and rounded endomastigotes with shallow flagellum pocket that attach to the surface of rectal glands. The second phase is the formation of special resettlement stages that can survive for some time in the drying host excrements (Frolov and Malysheva, 1992; Malysheva and Frolov, 1995). These specific stages called brochomastigotes are characterized by the loopshaped flagellum laying (Kostygov et al., 2014). A number of experiments have confirmed the possibility of parasite transmission between bugs while both predating and probing substrates were contaminated with feces of infected insects (Malysheva and Frolov, 1995).

C. brevicula is undemanding to food resources and is easily cultivated on simple media (Frolov and Malysheva, 1989b). These facts indirectly confirm the possibility of long-term existence of this parasite in decaying organic substrates. The decomposing organics contaminated with $C$. brevicula is likely to be an infection source for imagoes immediately on hatching from puparia or for feeding adult insects. Infected flies in turn can be an infection source for predatory bugs.

A wide range of $C$. brevicula hosts includes various representatives of at least two insect orders: Diptera and Hemiptera. Such low host specificity is generally not typical of monoxenous trypanosomatids and has been known only from single reports; so, this is not currently considered a common phenomenon. Symbiont-harboring species Angomonas deanei was first isolated from the intestine of reduviid bug Zelus leucogrammus (Carvalho, 1973), but later was found only in flies of Mucsidae, Calliphoridae and Sarcophagidae families (Teixeira et al., 2011; Týč et al., 2013). Another example of monoxenous trypanosomatids whose hosts belong to different orders of insects is Herpetomonas nabiculae, which has been repeatedly found in Nabicula flavomarginata bugs (Podlipaev, 1985). In Czech Republic, isolates of this species were recently obtained from fleas Chaetopsylla globiceps (Siphonaptera: Vermipsyllidae) and Paraceras melis (Siphonaptera: Ceratophyllidae), parasites of the common fox Vulpes vulpes (Votýpka et al., 2013).

Currently, C. brevicula is the only species whose geographical distribution does not extend beyond the Palearctic. This fact enables to assume that the origin and evolution of the parasite is associated with the Northern latitudes. The wide hostal range of the species allows suggesting that this multi-host parasitic system could be a result of the multiple $C$. brevicula transitions from the initial host. However, the original host of $C$. brevicula remains unknown.

\section{Acknowledgments}

This work was supported by the grant RFBR No 18-34-00867mol_a to AIG and AVZ, the grant RFBR No 19-34-90027 to AIG and AOF made in part within the frame of laboratory topic AAAAA19-119020690109-2 at Zoological Institute, Russian Academy of Sciences. 


\section{References}

Carvalho A.L.M. 1973 Estudos sobre a posição sistemática, a biologia ea transmissão de tripanosomatídeos encontrados em Zelus leucogrammus (Perty, 1834) (Hemiptera, Reduviidae). Rev. Pathol. Trop. 2, 223-274.

Cywinska A., Hannan M.A., Kevan, P.G. Roughley R.E., Iranpour M. and Hunter F.F. 2010. Evaluation of DNA barcoding and identification of new haplomorphs in Canadian deerflies and horseflies. Med. Vet. Entomol. 24, 382-410.

Flegontov P., Votýpka J., Skalický T., Logacheva M.D., Penin A.A., Tanifuji G. and Lukeš J. 2013. Paratrypanosoma is a novel early-branching trypanosomatid. Curr. Biol. 23, 1787-1793.

Frolov A.O. and Malysheva M.N. 1989a. Description of Crithidia allae sp. n. and Crithidia brevicula sp. n. (Protozoa, Trypanosomatidae) from the predator bug Nabis brevis Scholtz (Hemiplera, Miridae). Russ. J. Zool. 68, 5-10 (in Russian with English summary).

Frolov A.O. and Malysheva M.N. 1989b. The development cycle of the parasitic flagellate Crithidia brevicula (Trypanosomatidae) in laboratory culture. Tsitologiya. 31, 971-975 (in Russian with English summary).

Frolov A.O. and Malysheva M.N. 1992. Endomastigotes are a special type of resettlement stages of trypanosomatids of the genus Proteomonads. Parazitologiya. 26, 351-353 (in Russian with English summary).

Frolov A.O. and Malysheva M.N. 1993. Description of Phytomonas nordicus sp. n. (Trypanosomatidae) from the predatory bug Troilus luridus (Hemiptera, Pentatomidae). Parazitologiya. 27, 227-232 (in Russian with English summary).

Frolov A.O., Malysheva M.N., Ganyukova A.I., Yurchenko V. and Kostygov A.Y. 2017. Life cycle of Blastocrithidia papi sp. n. (Kinetoplastea, Trypanosomatidae) in Pyrrhocoris apterus (Hemiptera, Pyrrhocoridae). Eur. J. Protistol. 57, 85-98.

Frolov A.O., Malysheva M.N. and Kostygov A.Y. 2015a. Transformations of life cycles in the evolutionary history of trypanosomatids. Macrotransformations. Parazitologiya. 49, 233-256 (in Russian with English summary).

Frolov A.O., Malysheva M.N. and Kostygov A.Y. 2015b. Transformations of life cycles in the evolutionary history of trypanosomatids. Exotransformations. Parazitologiya. 49, 313-338 (in Russian with English summary).
Frolov A.O., Malysheva M.N., Yurchenko V. and Kostygov A.Y. 2016. Back to monoxeny: Phytomonas nordicus descended from dixenous plant parasites. Eur. J. Protistol. 52, 1-10.

Frolov A.O. and Skarlato S.O. 1995. Fine structure and adaptation mechanisms of lower trypanosomatids in the hemipteran insects. Tsitologiya. 37, 539-560 (in Russian with English summary).

Ganyukova A.I., Malysheva M.N. and Frolov A.O. 2017. Angomonas deanei (Kinetoplastida: Trypanosomatidae) in the fly Lucilia sp. (Diptera: Calliphoridae): description and cultivation of a new strain. Parazitologiya. 51, 387-398 (in Russian with English summary).

Hoare C. 1972. The trypanosomes of mammals. Blackwell Scientific Publications, Oxford.

Kostygov A.Y. and Frolov A.O. 2007. Leptomonasjaculum (Leger, 1902) Woodcock 1914: a leptomonas or a blastocrithidia? Parazitologiya. 41, 126-136 (in Russian with English summary)

Kostygov AY., Grybchuk-Ieremenko A., Malysheva M.N., Frolov A.O. and Yurchenko V. 2014. Molecular revision of the genus Wallaceina. Protist. 165, 594-604.

Kostygov A.Y. and Yurchenko V. 2017. Revised classification of the subfamily Leishmaniinae (Trypanosomatidae). Folia Parasitol. 64:020; doi: 10.14411/fp.2017.020.

Krivosheina N.P. 2008. Macromycete fruit bodies as a habitat for dipterans (Insecta, Diptera). Russ. J. Zool. 87, 1048-1061 (in Russian with English summary).

Malysheva M.N. and Frolov A.O. 1995. The development cycle of the flagellate Proteomonas brevicula (Trypanosomatidae) in predatory bugs of the family Nabidae (Hemiptera). Parazitologiya. 29, 289-297 (in Russian with English summary).

Malysheva M.N., Mamkaeva M.A., Kostygov, A.Y. Frolov A.O. and Karpov S.A. 2016. Culture collection of parasitic protists at the Zoological Institute RAS (CCPP ZIN RAS). Protistology. 1, 26-42.

Maslov D.A., Votýpka J., Yurchenko V. and Lukeš J. 2013. Diversity and phylogeny of insect trypanosomatids: all that is hidden shall be revealed. Trends Parasitol. 29, 43-52.

Ostroushko T.S., Panyukova E.V. and Pestov S.V. 2007. Dipteran insects (Insecta: Diptera) of the "gnat" complex of the fauna of the European north-east of Russia. Proc. Komi Sc. Cen. RAS. 183, 190-235 (in Russian).

Ozerov A. L. 2003. Black scavenger flies (Diptera, Sepsidae) of the fauna of Russia. Research 
on fauna (Vol. 45). Proc. Zool. Mus. MSU, Moscow (in Russian).

Podlipaev S.A. 1985. New species of lower trypanosomatids from the Heteroptera insects of the Gerridae and Nabidae families: life cycle in nature and during cultivation in the laboratory. Proc. ZIN AN USSR. 129, 35-47 (in Russian with English summary).

Podlipaev S.A. 1990. The world fauna of Trypanosomatidae (Protozoa). Cat. Proc. ZIN AS USSR (in Russian).

Podlipaev S. 2001. The more insect trypanosomatids under study-the more diverse Trypanosomatidae appears. Int. J. Parasitol. 31, 648-652.

Podlipaev S.A. and Frolov A.O., 1987. Description and laboratory cultivation of Blastocrithidia miridarum sp. n. (Mastigophora, Trypanosomatidae). Parazitologiya. 21, 545-552 (in Russian with English summary).

Podlipaev S.A. and Frolov A.O. 1999. Crithidia borea sp. n. - a parasite of Dixa sp. (Diptera: Dixidae). Parazitologiya. 33, 152-155 (in Russian with English summary).

Schoener E., Uebleis S.S., Cuk C., Nawratil M., Obwaller A.G., Zechmeister T., Lebl K., Rádrová J., Zittra C., Votýpka J. and Fuehrer H. P. 2018. Trypanosomatid parasites in Austrian mosquitoes. PloS One. 13, e0196052.

Schwarz R.S., Bauchan G.R., Murphy C.A., Ravoet J., de Graaf D.C. and Evans J.D. 2015. Characterization of two species of Trypanosomatidae from the honey bee Apis mellifera: Crithidia mellificae Langridge and McGhee, and Lotmaria passim n. gen., n. sp. J. Eukar. Microbiol. 62, 567-583.

Sedykh K.F. 1974. The animal world of the Komi ASSR. Invertebrates. Komi bookstore ed., Syktyvkar (in Russian).
Skidmore P. 1985. The biology of the Muscidae of the world (Vol. 29). Springer Science and Business Media.

Suchova M. 1950. New data on the ecology and epidemiolygical importance of the blue meat flies Calliphora uralensis Vill. and Calliphora erythrocephala Meig.(Diptera, Calliphoridae). Entomologicheskoe Obozrenie. 31, 1-2 (in Russian).

Teixeira M.M., Borghesan T.C., Ferreira R.C., Santos M.A., Takata C. ., Campaner M. and Camargo E.P. 2011. Phylogenetic validation of the genera Angomonas and Strigomonas of trypanosomatids harboring bacterial endosymbionts with the description of new species of trypanosomatids and of proteobacterial symbionts. Protist. 162, 503-524.

Tripodi A.D., Szalanski A.L. and Strange J.P. 2018. Novel multiplex PCR reveals multiple trypanosomatid species infecting North American bumble bees (Hymenoptera: Apidae: Bombus). J. Invertebr. Pathol. 153, 147-155.

Týč J., Votýpka J., Klepetková H., Šuláková H., Jirků M. and Lukeš J. 2013. Growing diversity of trypanosomatid parasites of flies (Diptera: Brachycera): frequent cosmopolitism and moderate host specificity. Mol. Phylogenet. Evol. 69, 255-264.

Votýpka J., Suková E., Kraeva N., Ishemgulova A., Duží I., Lukeš J., and Yurchenko V. 2013. Diversity of trypanosomatids (Kinetoplastea: Trypanosomatidae) parasitizing fleas (Insecta: Siphonaptera) and description of a new genus Blechomonas gen. n. Protist. 164, 763-781.

Yurchenko V., Votýpka J., Tesarová M., Klepetková H., Kraeva N., Jirku M. and Lukeš J. 2014. Ultrastructure and molecular phylogeny of four new species of monoxenous trypanosomatids from flies (Diptera: Brachycera) with redefinition of the genus Wallaceina. Folia Parasitol. 61, 97-112.

Address for correspondence: Anna Ganyukova. Zoological Institute, Russian Academy of Sciences, Universitetskaya Emb. 1, 199034 St. Petersburg, Russia; e-mail: anna.ganyukova@gmail.com 